園学雑. (J. Japan. Soc. Hort. Sci.) 61(1)：191-197. 1992.

\title{
サツマイモの表皮色拈よ゙表皮に含まれるアントシアニンの 生育中と貯蔵中における変化
}

\author{
宮崎丈史 \\ 千葉県農業試験場 266 千葉市緑区大噮野町 808
}

\begin{abstract}
Changes in Surface Color and Anthocyanins in the Periderm of Sweet Potato
(Ipomoea batatas L.) Cultivars During Growth and Storage.

Takeshi Miyazaki

Chiba Agricultural Experiment Station, Daizenno, Chiba 266
\end{abstract}

\begin{abstract}
Summary
Comparisons of surface color and anthocyanin composition in the periderm of four sweet potato (Ipomoea batatas L.) cultivars revealed that each was characteristically different.

1. 'Beniazuma' had the deepest red surface color and the anthocyanins were mostly nonacylated peonidin glycoside. On the contrary, the anthocyanins in 'Beniaka' periderm were mostly acylated and consisted of nearly $25 \%$ cyanidin glycoside.

2. During the growth and development of sweet potatoes, two anthocyanins in the periderm, peonidin-3GG (glucosylglucoside)-5G (glucoside) and p-hydroxybenzoyl-peonidin-3GG-5G increased significantly; whereas, the concentrations of those with cinnamic acid derivatives remained nearly constant.

3. The absorbance at $525 \mathrm{~nm}$ of $\mathrm{HCl}$-methanolic extracts of the periderm decreased by 20 to $30 \%$ after storage at $13^{\circ} \mathrm{C}$ for 6 months; and it decreased during the curing treatment. Wrapping the storage container with polyethylene film $(0.03 \mathrm{~mm}$ thickness) created an environment with a high humidity, suppressed weight loss, and made the surface color lighter. It seemed that high humidity (ca. 95\% RH) was suitable for maintaining the surface color of sweet potatoes during the storage at $13^{\circ} \mathrm{C}$.
\end{abstract}

\section{緒 言}

サツマイモは，形状，大きさ，食味とともに，表皮 色の良否によって市場評価がなされている，表皮色は 濃い鮮紅色であることが望ましいとされているため， 青果用サツマイモの栽培はより濃い表皮色をもつ品種 や系統に移行している。

サツマイモの多くは秋に収穕され，その後約半年間 にわたって眝蔵・出荷される，その間，表皮色はさま ざまな影響を受け，全体的に淡色化したり䶕を失うだ けでなく, 斑状の変色なども生じる。これらの変化は 直接価格に影響するため, 貯蔵中における表皮色の保 持はサツマイモの生産・流通にたずさわる者の切実な 要望となっている。

1990 年 8 月 9 日 受理.
サツマイモの表皮色を構成している色素はアントシ アニンであり，著者らはその構造をシアニジンとぺオ ニジンの配糖体およびこれらにカフェ酸やフェルラ酸 あるいはかーヒドロキシ安息香酸が結合したものであ ることを明らかにした（宮崎ら，1991）。本報告では， サツマイモの品質保持の一環として, 生育中および貯 蔵中における表皮色とそのアントシアニン組成の変化 を調查し，表皮色の保持に適した貯蔵条件などについ て検討した。

\section{材料および方法}

供試したサツマイモ（塊根）ば紅赤，“べニアズマ’， ‘ベニコマチ’, ‘紅高系の 4 品種である.このうち, ‘゙ ニコマチ’と紅高系については収穝時における表皮ア ントシアニンの比較にのみ用いた。 サツマイモは千葉県農業試験場あるいは農家の固場 
で慣行栽培し，5 月下旬に苗を植え付けて 10 月中〜下 旬に収穫した。各圈場とも土靖は表層腐植質黒ボク土 であるが，前作歴や土壌の化学性・物理性などは異な っている.

生育期間中の表皮色の調查は 1988 年と 1989 年に行 い，“紅赤とい゙ニアズマ’を植之付け 3 か月，4 か月お よび 5 か月後に各区 10 株ずつ掘り取って調査した.

貯蔵試験は‘紅赤と‘べニアズマ’を用いて·1985〜19 89 年に行い, 収穫した塊根を藷梗より切り離して 30 $\mathrm{kg}$ 用のプラスチックコンテナに入れ, $13^{\circ} \mathrm{C}$ 貯藏庫に保 管した。 1 調査区の販藏塊根数は 100～250本とした。

表皮色に及ぼす販蔵処理の影響をキュアリング処理 と貯蔵湿度について調査した。キュアリング処理は $30{ }^{\circ} \mathrm{C}$, 約 $98 \%(96 \sim 100 \%)$ の相対湿度 (RH) で7 日 間行った．貯蔵湿度は包装処理によって変化させ, 無 包装，ポリシート外包装（コンテナを穔み重ねてブロ

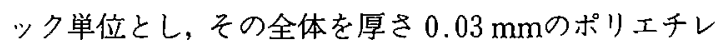
ンフィルムで底面のみを開放して包む）呫よびポリシ 一ト内包装 (厚さ $0.03 \mathrm{~mm}$ のポリエチレンフィルムを コンテナの中に敷き，これに塊根を入れて上部を折り 込み，全体を包む）の各区を設けた，包装処理区は塊 根の重量減少率を調查するとともに，包装内の湿度を 湿度計 (MGC八イグロメーター, 三菱瓦斬化学製)で 測定した。また，塊根をポリシート内包装処理して $20^{\circ} \mathrm{C}$ に保管するとともに，同様の処理を溝穴盯蔵にお いても行い，表皮の退色に及はす寸湿度と温度の影暗を 調查した。

表皮色の調查は，生育中および貯蔵中の実験とも， 1 調查区当たり 9 - 15 本の塊根を用いて 3 亿反復 した。“L”, “a”および “b”值は塊根を洗净・風乾 したのち, 色差計 (CR-100, ミノルタカタラ製)によ って測定した。また，表皮より色素を抽出し，吸光度 の測定とアンシトアニン色素の分析を以下のように行
った：打ち抜き器により塊根の表皮から一定の面積 $\left(8 \mathrm{~cm}^{2}\right)$ をサンプリングし，これに $1 \%(\mathrm{~V} / \mathrm{V})$ 塩酸メタノールを加えて磨砝・抽出する。抽出液は $100 \mathrm{ml}$ に定容とした後遠心分離し, 上澄を得る.上澄液の吸 光度は分光光度計（UV-2100，島津製作所製）を用い， $525 \mathrm{~nm}$ の波長で測定する. 表皮抽出液のアントシアニ ン色素の分析は, 高速液体クロマトグラフィー （HPLC）を用いて前報（宮崎ら，1991）と同様の方法 で行った. アントシアニン色素はアグリコンおよびア シル化の有無によってグループ化し，クロマトグラム のピーク面積值をそれぞれのグループごとに合計して その割合を求めた。

\section{結 果}

\section{1.表皮アントシアニンの品種間差異}

表皮の色調を異にしだ紅赤”、ベニアズマ’、‘゙ニコ マチ’, ‘紅高系’の 4 品種について, 表皮抽出液の吸光度 とアントシアニン成分を分析した. 表皮抽出液の吸光 度は, 表皮色の濃いぶニアズマ’が約 1.0 と最も高く, 他の品種はおおむね $0.3 〜 0.6 の$ 範囲にあった。

アントシアニンは各品種ともほほ同様な成分を含ん でいたが，その組成には差が認められた，第 1 表に品 種毎の組成比を示したが，“紅赤”は P-6 と P-10, “べ アズマは P-3, ‘゙ニコマチ’は P-3と P-6,また紅高系” はP-11の比率に特徴があった。

成分をアグリコンの種類に分けたものを第 1 四にま たアシル化の有無別に分けたものを第 2 図に示した. アグリコン別ではぺオニジンがいずれの品種でも多く， 75〜95\%を占めていた。一方，シアニジンは最も多い ‘紅赤でも約 $25 \%$ であり,‘゙ニアズマ’では $5 \%$ 程度に 過ぎなかった。アシル化アントシアニンは, ‘紅赤てでは 80 \%以上を占めたが, ‘ベニアズマ’では $40 \%$ と少なか つた。

\section{2. 生育中における变化}

Table 1. Anthocyanin composition ${ }^{\mathrm{z}}$ in the periderm of four sweet potato cultivars.

\begin{tabular}{|c|c|c|c|c|c|c|c|c|c|c|}
\hline \multirow{2}{*}{ Cultivars } & \multicolumn{9}{|c|}{ Proportion of HPLC peak area (\%) } & \multirow[b]{2}{*}{ P-12 } \\
\hline & P-1 & $P-3$ & P-4 & P-6 & P-7 & P-8 & P-9 & $\mathrm{P}-10$ & $P-11$ & \\
\hline Beniaka & 6 & 13 & 6 & 22 & 2 & 6 & 6 & 24 & 10 & 3 \\
\hline Beniazuma & 4 & 54 & 2 & 20 & 2 & - & 1 & 6 & 9 & - \\
\hline Benikomachi & 5 & 25 & 9 & 27 & 2 & 2 & 1 & 18 & 10 & - \\
\hline Benikokei & 4 & 19 & 2 & 19 & 4 & 2 & 5 & 17 & 19 & 7 \\
\hline
\end{tabular}

" P-1: cyanidin-3GG(glucosylglucoside)-5G(glucoside), P-3: peonidin-3GG-5G, P-4: p-hydroxybenzoyl-cyanidin-3GG-5G, P-6: p-hydroxybenzoyl-peonidin-3GG-5G, P-7: feruloyl-peonidin-3GG-5G, P-8: caffeoyl-p-hydroxybenzoyl-cyanidin-3GG-5G, P-9: caffeoylcyanidin-3GG-5G, P-10: caffeoyl-p-hydroxybenzoyl-peonidin-3GG-5G, P-11: caffeoyl-peonidin-3GG-5G, P-12: caffeoyl-feruloylpeonidin-3GG-5G. 
生育中における表皮色の変化は，品種や栽培条件に よって異なった. 1988 年に調查した表皮抽出液の吸光 度の変化を第 3 四に示した。年度や栽培围場を変えて 調查したところ, ベニアズマ’はほとんどが第 3 図と同 粎に生育期間とともに吸光度は高くなったが, ‘紅赤で゙ は‘ベニアズマ’のような傾向は認められなかった。

生育中に扔汁るアントシアニン成分の変化をHPLC クロマトグラムのピークでみると，“紅赤では P-3,

P-6，P-11が生育とともに溸增し，P-12が減少した。ま た，最も量的に多いP-10は変化が少なかった。い゙ニア ズマ’では P-3の増加が顕著であり，P-6も増加した(第 4 図).また，吸光度はHPLC分析によるアントシアニ ンのピーク面積値の合計と良い比例関係を示した。

\section{3. 貯藏中の変化}

貯蔵中における表皮色の変化を調查した。塊根表皮 を色差計を用いて測定したところ，“゙ニアズマ’ど紅 赤は販藏中に同様の測色值変化を示し, “a ”值が減少 して“ “ b”值は增加したが “L”值はあまり変化しな かった(第 5 図)。また, “a”值の減少は収穫直後に

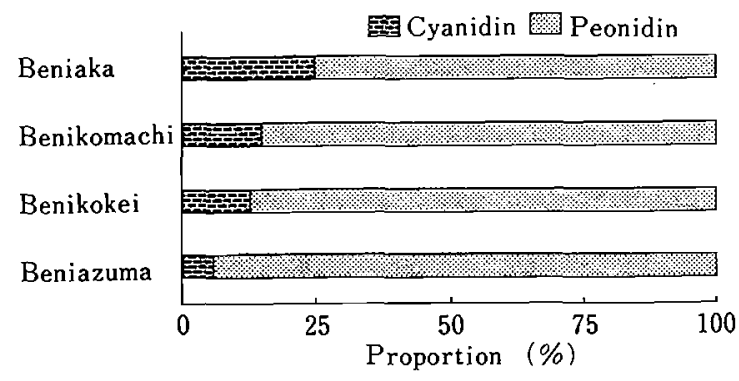

Fig. 1. Aglycone proportion of anthocyanins in the periderm of four sweet potato cultivars.

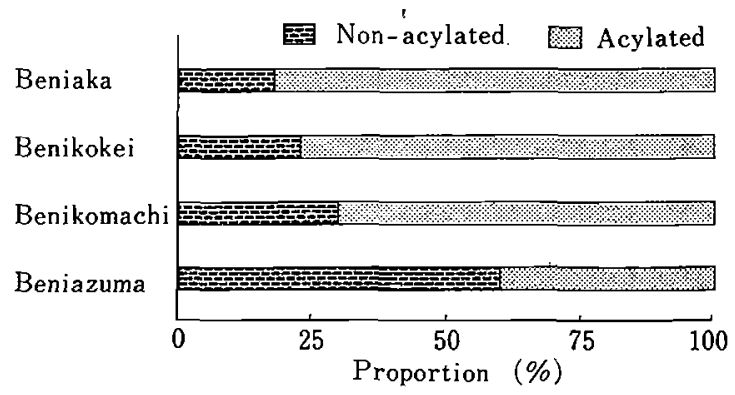

Fig. 2. Proportion of non-acylated to acylated anthocyanins in the periderm of four sweet potato cultivars.
大きかった。

表皮抽出液の吸光度の変化を第 6 図に示した。吸光 度の低下岋収穫直後に岋少なかったが，貯藏後半にゃ や多くなった，貯藏 6 か月後の表皮抽出液の吸光度は 収穫時に比べて 2 - 3 割減少したが,“紅赤’表皮色の 淡い系統では娍少割合が 5 割にも達するものがあった。

表皮色は，販蔵処理によって以下のように変化した。 1)キュアリング処理による影響

表皮色へのキュアリング処理の影響を第 2 表に示し た、キュアリングによっで紅赫と‘゙ニアズマ’の表皮 抽出液の吸光度は, 処理直後に $15 \sim 20 \%$ 減少した.ア

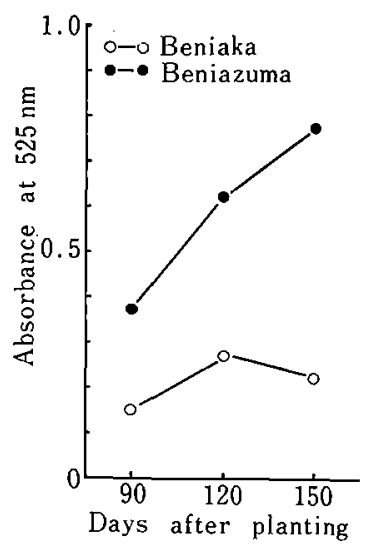

Fig. 3. Changes in the absorbance of the $1 \% \mathrm{HCl}$ methanolic extracts of sweet potato periderms during growth and development.

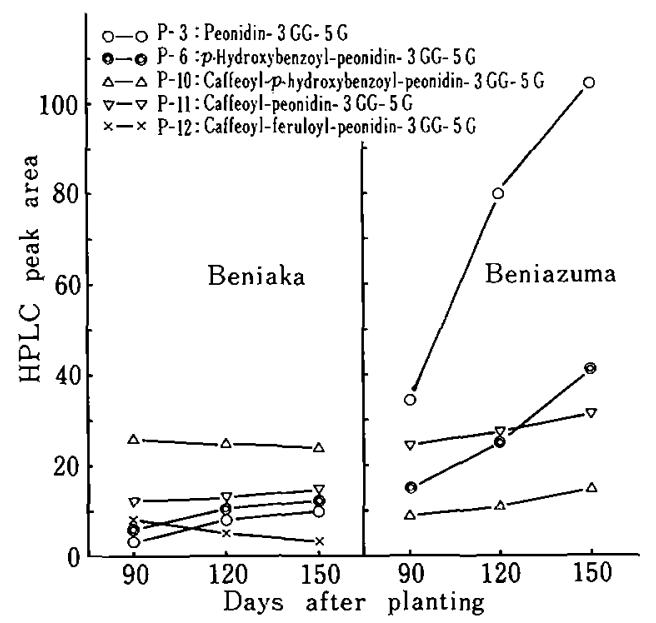

Fig. 4. Changes in the anthocyanin compositions of sweet potato periderms during growth and development. 


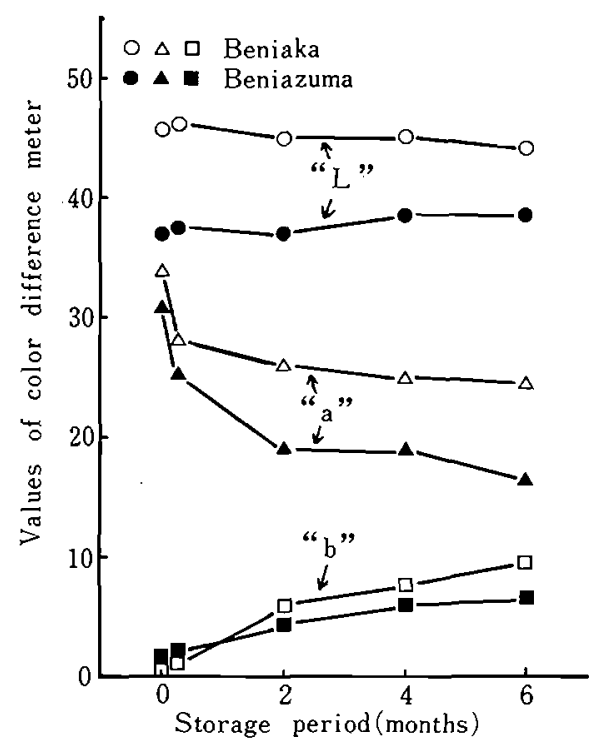

Fig. 5. Changes in "L", "a", "b" values of sweet potato surface colors during storage at $13^{\circ} \mathrm{C}$.

ントシアニン成分毎の変化を見ると,P-6の減少程度は やや小さかったが，各成分と当全体的に減少した。こ のため，アントシアニン組成比の変化は少なかった。

キュアリング処理区の表皮抽出液の吸光度は，貯蔵 中に無処理区とほぼ同様に変化したため，眝藏 6 か月 後には収穫時に比べて 30 ～ $40 \%$ の減少となった(第 6 図)。また，6か月販藏後のキュアリング処理区のアン トシアニン成分は，“ベニアズマ’と紅赤の両品種とも， カフェ酸を結合したアシル化アントシアニンの割合が 少なくなった（第 3 表).

キュアリング処理によって表皮の色調も変化し, ‘゙ ニアズマ’や表皮色が濃い系統の'紅赤ではやや赤みを 带び, 表皮色の淡い系統の紅赤では明らかに薄くなっ た。

\section{2）包装処理による影㛙}

貯蔵中における塊根の環境湿度は包装処理によって 異なり，重量減少にも差異が生じた，販藏庫をはぼ塊 根でいっぱいにしな場合の湿度は，無包装区で 88～-92 \%，ポリシート外包装区で $95 \%$ 前後，ポリシート内包 装区で $98 \%$ 以上となり, 貯蔵 6 か月後の塊根の重量減

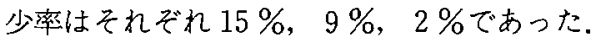

表皮色は，貯蔵中に重量減少の多い区ほど齵がなく なり暗赤色化した。湿度が高く重量隇少のはとんどな

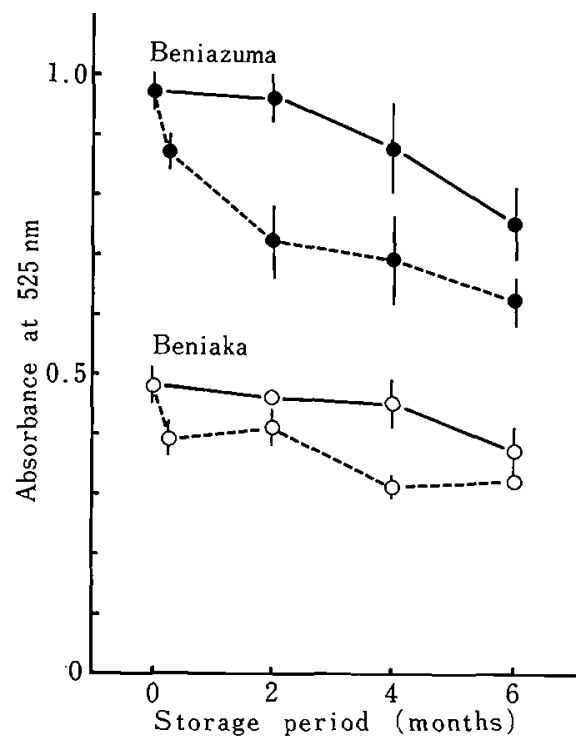

Fig. 6. Changes in the absorbance of the $1 \% \mathrm{HCl}$-methanolic extracts of sweet potato periderms during storage at $13^{\circ} \mathrm{C}$. Solid and dotted lines represent uncured and cured treatment, respectively. Vertical bars indicate standard deviations.

いポリシート内包装区では，表皮色が収穫時により近 い色調を保持していた。しかし，ポリシート内包装区 では $13^{\circ} \mathrm{C}$ 貯蔵 4 か月以降になると, 塊根表皮に斑状の 変色が認められるようになった。斑状の変色は，ポリ

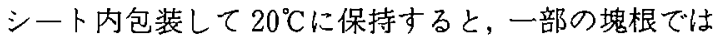
2 週間後にも発生が見られた。また， $20^{\circ} \mathrm{C}$ 前後の㵆度 で推移しな满穴でのポリシート包装販蔵では，1か月 後に斑状の変色が多発していた。

貯藏中の‘紅赤の表皮を色差計で測定したところ，第 7 図のような測色值変化を示した。高湿度条件はど， “ $\mathrm{L} "$ 值と“ $\mathrm{a}$ ”值は高くなったが“ $\mathrm{b}$ ”值は低く推移 した。このため, “ $\mathrm{L}$ ‘“ 経過するにつれ、また湿度が低いはど収穕時より離れ た值を示した。

包装処理の違いによるアントシアニン成分の変化を 第 8 図に示した。高い湿度のポリシート内包装区では 非アシル化アントシアニンである P-3の割合が多くな ク,アシル化アントシアニンである P-6やP-10の割合 は減少した。

サツマイモの表皮色は市場性評価の大まな要素とな 
Table 2. Changes in the absorbance and anthocyanin composition of the extracts ${ }^{z}$ of sweet potato periderms after curing treatment.

\begin{tabular}{llcccccc}
\hline \hline \multirow{2}{*}{ Cultivar } & \multirow{2}{*}{$\begin{array}{c}\text { Curing } \\
\text { treatment }\end{array}$} & \multirow{2}{*}{$\begin{array}{c}\text { Absorbance } \\
\text { at } 525 \mathrm{~nm}\end{array}$} & \multicolumn{5}{c}{ Proportion of HPLC peak area ${ }^{\mathrm{y}}(\%)$} \\
\cline { 5 - 8 } Beniaka & No & 0.48 & 4 & 15 & 26 & 26 & 9 \\
& Yes & 0.39 & 4 & 13 & 29 & 25 & 8 \\
Beniazuma & No & 0.97 & 5 & 56 & 21 & 5 & 10 \\
& Yes & 0.84 & 5 & 55 & 22 & 4 & 10 \\
\hline
\end{tabular}

z $1 \%(v / v) \mathrm{HCl}$-methanol solution.

y Peaks are the same as those in Table 1.

Table 3. Anthocyanin composition in the periderm of sweet potato stored at $13^{\circ} \mathrm{C}$ for 6 months.

\begin{tabular}{llccccc}
\hline \multirow{2}{*}{$\begin{array}{l}\text { Cultivar } \\
\text { Curing }\end{array}$} & \multicolumn{5}{c}{ Proportion of HPLC peak area ${ }^{2}(\%)$} \\
\cline { 3 - 7 } & treatment & P-1 & P-3 & P-6 & P-10 & P-11 \\
\hline \multirow{2}{*}{ Beniaka } & No & 3 & 10 & 23 & 32 & 8 \\
& Yes & 3 & 12 & 31 & 27 & 7 \\
& No & 3 & 40 & 18 & 9 & 19 \\
& Yes & 3 & 43 & 22 & 4 & 11 \\
\hline
\end{tabular}

${ }^{2}$ Peaks are the same as those in Table 1.

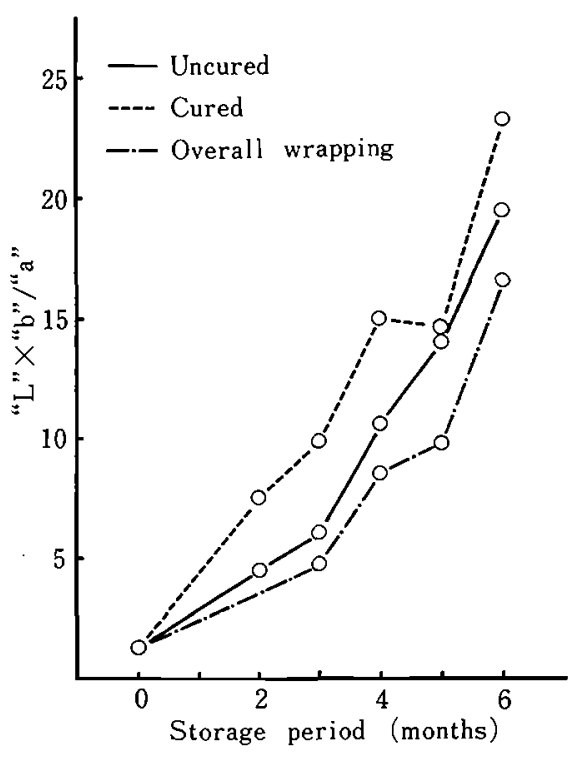

Fig. 7. Effects of curing or wrapping with $0.03 \mathrm{~mm}$-thick polyethylene film on surface color of 'Beniaka' sweet potatoes stored at $13^{\circ} \mathrm{C}$.

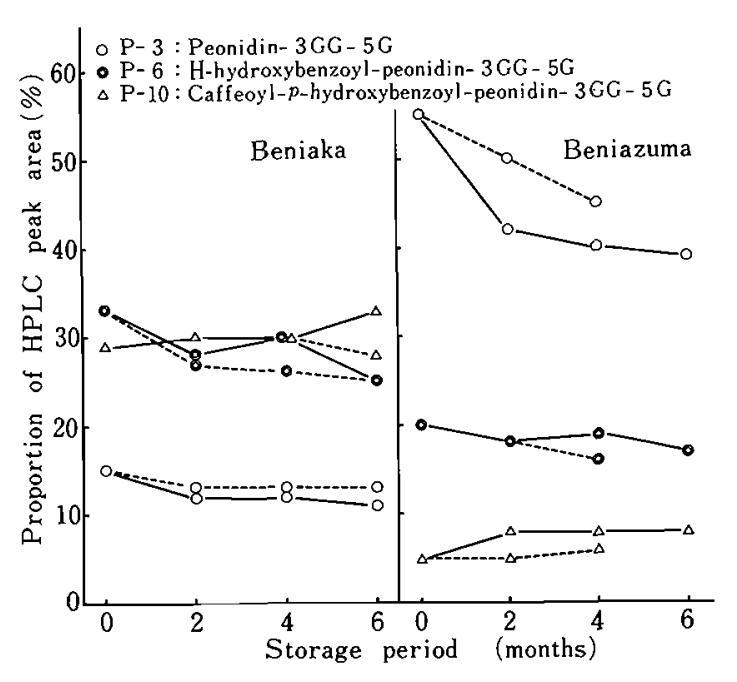

Fig. 8. Effects of wrapping containers with $0.03 \mathrm{~mm}$-thick polyethylene film on anthocyanin compositions in the periderm of two sweet potato cultivars stored at $13^{\circ} \mathrm{C}$. Solid and dotted lines represent open-end (bottom end is open) and overall wrapping, respectively. 
つているため，品種選抜などにおいても表皮色の占め る位置は大きくなっている。しかし，表皮色について の研究は栽培関係でも報告が叒めて少ない（金田ら， 1975 ; 加藤·中山，1975）。表皮色は同じ苗を用いても 栽培条件などによって濃淡が生じるが，表皮色の濃い 塊根はデンプン含量も多い傾向が認められた（未発 表)。供試した品種中“ベニアズマ’は浱い表皮色を有し 食味もよいため，市場流通においては高い評価を得て いる。一方， ベニアズマ’に比べて表皮色の淡い紅赤” がよい市場評価を得るためには，本報に示した表皮抽 出液の吸光度で 0.35 以上の濃さが必要と考之られた。

色調の異なる 4 品種の表皮色素を分析したところ， 主要なアントシアニンは 13 成分中の 6 ～ 8 成分であ り，それぞれアシル化アントシアニンの組成比などに 特徵が見られた。組成比は同一品種であっても生育状 態や苗の種類などによってやや変化し, ‘紅赤”選抜系 統中表皮色の濃い横山系では在来系に比べてぺオニジ ンの比率が高まった．しかし，表皮のアントシアニン 構成は品種によって特徴があるため，これを品種や系 統の判別に用いることも可能と思われた.

アシル化アントシアニンを多く含むサツマイモの色 素は，その安定性のために食品への応用も注目されつ つある（Bassa・Francis, 1987）。塊根表皮のアシル化 アントシアニンはカフェ酸やpーヒドロキシ安息香酸 を結合しており，植物色素中に最も多く見いだされる pークマール酸は含まれていない（宮崎ら，1991）。ま た，自然界では ントシアニンは少ない（Asenら，1979；Kondoら， 1990）が，サツマイモ表皮色素中にはこれらが多く含 まれていることも特徽的である。

表皮色の生育中における変化は紅赤と“ベニアズマ’ では差が認められたが, アントシアニン組成をみると P-3と P-6 (P-3に 1 分子のpーヒドロキシ安息香酸が結 合）の 2 成分が両品種に共通して増加した。紫サツマ 亿モの表皮と塊根内部の色素を比較・検討した結果, これらのアントシアニンは塊根内部には存在せずに表 皮に局在して打り，両者ともカフェ酸を結合していな いことが明らかにきれている(宮崎ら，1991)，カフェ 酸はアントシアニン生合成経路で重要な位置を占める ことをKamsteegら (1980) が報告しているが, サッマ イモ塊根の生育・肥大期において，その表皮中にカフ エ酸を結合したアントシアニンのみるべき増加がない ことは注目される。

収穫したサツマイモの貯藏は，ほとんどが溝穴や貯
藏庫で行われる，貯藏庫を用いた貯藏においては，キ ュアリング処理や温度・湿度の管理が行われる，貯藏 処理による表皮色の変化を見ると，キュアリング処理 によって表皮色は変化したが, ‘゙ニアズア’や䓾い系統 の゙紅赤では赤味のある色調であったため，評価はそれ ほど低下しなかった。

一方, 包装処理による湿度環境の変化も表皮色に影 響を与え，湿度が低いほど表皮色は暗赤色となった。 これに対し，湿度が高くなると表皮色はやや淡くなっ たが，色調はむしろ収穫時に近かった，異なる湿度環 境下で眝蔵されたサツマイモの表皮アントシアニンの 組成変化を見ると, $100 \%$ RHに近いポリシート内包装 区ではP-3などの非アシル化アントシアニンが多くな った.こうしたことから，湿度環境を異にした際に生 じる色調の違いには，色素の量だけではなく組成的な 差も影贸していると考えられた。

溝穴などに貯藏されたサツマイモの表皮には，しば しば斑状に茶色あるいは黒褐色の変色が発生する。甚 しく変色したサツマイモは価格が半值以下となるため， 满穴眝蔵の多い生産地では大きな問題となっている。 また, ‘゙ニアズマ’を高湿度環境下で 4 か月以上敗蔵す ると, 斑状の変色だけでなく表皮そのものに劣化が生 じた。貯蔵庫と溝穴での貯蔵による実験から，斑状の 変色はサツマイモが $100 \%$ RHに近い高湿度状態下に おかれることによって生じ, 高温がこの変化を加速す るものと推察された。このため, 貯蔵に際して表皮色 の変化を防止する観点からは, $20^{\circ} \mathrm{C}$ 以上の高温時には 高湿度との併存を避け, 温度を $15^{\circ} \mathrm{C}$ 以下まで低下させ た後に $95 \% \mathrm{RH}$ 程度の湿度を保つことが適切と考え られた。

\section{摘 要}

サツマイモ表皮色と表皮アントシアニンの品種間差 異および生育中と貯藏中における変化について調查し， 以下のような結果を得た。

1，サツマイモの表皮色を構成するアントシアニン は，4品種ともぺオニジン配糖体が多くシアニジン配 糖体は少なかった。また，アシル化アントシアニンは “紅赤に多く，〔゙ニアズマ’はは少なかった。

サツマイモ表皮の1\%塩酸-メタノール抽出液の吸 光度は色の濃淡とよく一致し, 最も濃いベニアズマ’は “紅赤などの品種に比べて約 2 倍の吸光度を有してい た。

2 , 生育中に, 表皮特有のアントシアニン成分であ るP-3 (ペオニジン 3 -ジグルコシド 5 -グルコシド) と 
P-6（p-ヒドロキシベンゾイルペオニジン 3 -ジグルコ シド5ーグルコシド)が，“紅赤抽よ゙べニアズマ’共 通して増加した。

3 ，貯蔵中に表皮色は変化し，貯蔵 6 か月後には表 皮抽出液の吸光度で $2 \sim 3$ 割減少した。 また，表皮色 はキュアリング処理によっても約 2 割減少した。

貯藏湿度を $100 \% \mathrm{RH}$ 近くに高めると，表皮色は収 㮃時に近い色調を保つもののやや淡くなり，貯蔵 4 か 月以降には一部に斑状の変色なども生じた。このため, 4〜6月間の長期貯藏におけるサッマイモ表皮色の保 持には， $13^{\circ} \mathrm{C} て ゙ 95 \% \mathrm{RH}$ 程度の貯藏㻴境が適している ものと考之られた。

謝 辞 本研究の遂行に際し，終始激励をいただいた 千葉県農業試験場流通利用研究室長新堀二千男氏と試 料の提供などに協力していただいた同畑作研究室，土 壤肥料研究室扔よび烟作営農研究室の皆樣に感謝いた します。

\section{引用文献}

Asen, S. , R. N. Stewart and K. H. Norris. 1979.
Pelargonidin 3-DI ( $p$-hydroxybenzoyl) rutinoside7-glucoside from flowers of Campanula. Phytochem. $18: 1251-1252$.

Bassa, I. A. and F. J. Francis. 1987. Stability of antyocyanins from sweet potatoes in a model beverage. J. Food Sci. 52 : 1753-1754.

Kamsteeg, J. , J. V. Brederode and G. V. Nigtevecht. 1980. Genetical and biochemical evidence that the hydroxylation pattern of the anthocyanin B-ring in Silene dioica is determined at the $p$ coumaroyl-coenzyme A stage. Phytochem. 19: 1459-1462

金田雄二・河森 武・伏見 弘・石上 清 - 大橋義弘。 1975. 園芸作物の品質と土壤環境に関する研究.（第 1 報).カンショ“高系 14 号’の皮色に及ばす土壤環境 の影響について。静岡農試研報。 $22: 24-31$.

加藤徹・中山信弘。1975.サツマイモ熄根の着色に関する 研究. 高知大学研報 (農学)。24:87-96

Kondo, T. , K. Oki, K. Yoshida and T. Goto. 1990. Structure of violdelphin, an anthocyanin from violet flower of Delphinium hybridum. Chemistry Letters : 137-138.

宮崎文史・都築和香子・鉿木建夫. 1991.サツマイモに含 まれるアントシアニンの組成と棈造について。園学 雑, $60 ： 217-224$. 